\title{
Does Globalization Encourage Female Employment? A Cross- Country Panel Study
}

\author{
Asrifa Hossain ${ }^{1}$, Shankar Ghimire ${ }^{2, *}$, Anna Valeva ${ }^{3}$, and Jessica Harriger-Lin ${ }^{4}$ \\ 1 School of Accounting, Finance, Economics, and Decision Sciences, Western Illinois University, 1 University \\ Circle, Macomb, IL 61455; a-hossain2@wiu.edu \\ 2 School of Accounting, Finance, Economics, and Decision Sciences, Western Illinois University, 1 University \\ Circle, Macomb, IL 61455; sp-ghimire@wiu.edu \\ 3 School of Accounting, Finance, Economics, and Decision Sciences, Western Illinois University, 1 University \\ Circle, Macomb, IL 61455; ak-valeva@wiu.edu \\ 4 School of Accounting, Finance, Economics, and Decision Sciences, Western Illinois University, 1 University \\ Circle, Macomb, IL 61455; jl-lin@wiu.edu \\ * Correspondence: sp-ghimire@wiu.edu; Tel.: +1-309-298-1153
}

\begin{abstract}
This study assesses the impact of globalization on female participation in the labor force (FPLF). The increased globalization in the last several decades has created various economic opportunities for enterprises and individuals worldwide at an unprecedented rate. As a result, it has helped improve the quality of life for many men and women. In this process, the issue of women's economic participation has been a critical topic for discussion worldwide. In that context, the objective of the paper is to determine if FPLF is influenced by a country's participation in foreign markets through foreign direct investment (FDI) - a proxy for globalization. The paper uses a panel dataset obtained from the World Bank's World Development Indicators database for 99 countries from 2001 to 2018. We then use system Generalized Method of Moments (system GMM) to estimate a dynamic panel model with appropriate specification tests. The results show that the positive effects of FDI on FPLF are more robust for low- and middle-income countries than high-income countries. We also find that results may be sensitive to outlier observations. Our results explain the seemingly inconclusive results within existing literatures and suggest that low- and middle-income countries should particularly focus on sectors that generate FDI as they stand to yield the greatest benefits with regards to female economic empowerment.
\end{abstract}

Keywords: Female Participation in Labor Force (FPLF), Foreign Direct Investment (FDI), System GMM

\section{Introduction}

Globalization can be viewed as a remarkable world integration leading to an exchange of ideas in different cultural, economic, political, technical, and social spheres. Globalization's impact on the receiving country's economic outcomes is an established phenomenon. The existing literature illustrates the connection between globalization and women's economic outcomes (Chopra, 2019; Okpak \& Koyuncu, 2017; Wacker et al., 2017; Maqsood, 2014). However, globally only about 55 percent of women participate in the labor force, compared to 80 percent for men. Among the employed, women still earn about $50 \%$ less than men for the same type of work (Lagarde et al., 2016). These gender disparities serve as an important focal point for research related to female employment as it has a significant positive association with social, economic, and overall globalization (Okpak \& Koyuncu, 2017).

Numerous studies attempt to understand the forces that may improve women's economic outcomes. For instance, Tasseven et al. (2016) find that GDP per capita, unemployment rates, and fertility rates significantly affect women's employment. Urbanization, 
FDI, GDP per capita, and economic growth are the most significant contributors to improving gender equality and education (Sajid, 2014). Abdulloev et al. (2014) further demonstrate that by acquiring higher education, females can significantly reduce gender gaps. Similarly, information and communication technology, law, and order also influence females' status in Pakistan (Sajid, 2014). While multiple factors affect women's employment, this article particularly focuses on the relationship between globalization and female participation in labor force (FPLF).

While globalization may seem an immeasurable concept, Maqsood (2014) determines that it is significantly driven by the factors of production, FDI, and trade flows. Therefore, expanding FDI serves as a reasonable proxy for rising economic globalization. A very large body of research investigates the relationship between FDI, trade, and gender economic disparities. It is generally believed that increased globalization creates job opportunities for females and reduces gender disparities. Trade liberalization (as a founding pillar of economic globalization) has positively influenced women's economic status (Richards \& Gelleny, 2007). Technology and trade contribute to Turkey's employment creation, and FDI implies an absolute skill bias (Meschi et al., 2016). Both push factors (unemployment) and pull factors (trade liberalization) influence Brazilian women to join the labor market (Gaddis \& Pieters, 2012). Chopra (2019) shows that FDI inflows significantly and positively affect women's empowerment and increase women's welfare. FDI and urbanization have boosted FPLF, particularly in the SAARC region. FDI encourages women's employment opportunities in the telecommunication, services, and pharmaceuticals sectors (Maqsood, 2014).

However, the aggregate empirical analysis of globalization, particularly FDI inflows, and the country's domestic gender wage gap is inconclusive (Carr, 2016). For instance, Vijaya and Kaltani (2007) find that female salaries and manufacturing wages are negatively correlated with FDI net inflows. This reduces female labor's bargaining power due to the global economy's arrangement where countries invest in more convenient conditions. Ouedraogo and Marlet (2018) find a positive association between FDI inflows and gender development but a negative correlation between FDI and gender inequality. This relationship is stronger in Sub-Saharan Africa, the Middle East \& North Africa, Latin America, and middle-income countries. This implies that while expanded FDI may increase economic opportunities for women, it does so less than proportionately. Similarly, Cooray et al. (2017) analyze the effect of trade openness and political institutions on female employment in 48 countries of Sub-Saharan Africa from 1985-2012. They find that while political institutions play a crucial role in enhancing trade openness, and trade liberalization can generate more employment opportunities and economic efficiency, the benefits fall more heavily on men. Bussmann (2009) further demonstrates the nuances in understanding globalization's impacts as he demonstrates that trade deficits are positively correlated with FPLF in developing countries but negatively associated with FPLF in OECD countries. Along with discrepancies by gender and region, the economic benefits from globalization also vary by age, as seen in Wacker et al. (2017). They investigate the link between trade and FDI on female employment with a panel of 80 developing countries from 1990-2005 and demonstrate a negative association between globalization (FDI/trade) and FPLF. Their results are more substantial for young groups as globalization generates a robust incentive to invest more in education, thereby delaying labor force participation. Although the general belief that globalization positively promotes overall labor force participation holds throughout the literature, the distribution of these benefits varies significantly by gender, region, age, and other factors.

This paper contributes to the literature in several ways. First, we carefully analyze the percentage of women that are in the labor force, using a global dataset that allows us a broader view than the traditional subset approach provides. This analysis allows us to fully establish the female labor force participation rate relative to that of men. Second, we examine the relationship between FDI and FPLF by using a system GMM approach that helps address potential endogeneity, a common issue in lag-dependent dynamic panel data analysis. Third, we highlight the role of other explanatory variables in increasing the 
female labor force participation and try to present a broader view of the issue across the world.

The remainder of the paper is organized as follows. Section 2 presents the conceptual framework; Section 3 details the data and methodology; Section 4 presents the empirical results and discussion; finally, Section 5 concludes with a summary.

\section{Conceptual Framework}

The motivation to study the relationship between globalization and women's labor force participation stems from two contradictory hypotheses: 1) globalization as measured by FDI and trade openness may have a positive impact on FPLF by creating new economic opportunities, and 2) these factors may reduce FPLF by making the labor market more competitive for women (Maqsood, 2014). Existing literature finds mixed results regarding these hypotheses, as we present them below.

Improvements in the business climate, trade openness, and FDI generate employment opportunities for female labor. Multinational corporations can easily hire the cheapest female workers from countries with emerging economies, thus increasing FPLF (Gaddis \& Pieters, 2012; Seguino \& Grown, 2006, Richards \& Gelleny, 2007).

On the other hand, FPLF may be negatively associated with trade openness and FDI inflows as globalization promotes a competitive business environment in the receiving country. Low-income countries receive a large share of FDI in the primary sector, relying on physical human capital (Ouedraogo \& Marlet, 2018). To compete in this sophisticated globalized world, countries raise the level of their labor force skills by investing more in young women's education and, hence, reducing their labor market participation (Wacker et al., 2017). In Southeast Asia, FDI inflows negatively impact gender development as these countries receive a plethora of investments in the technological sector which relies predominately on skilled labor, thus benefiting male labor. In low-income countries, male employment increases more than female labor (Cooray et al., 2017; Ouedraogo \& Marlet, 2018).

Against the backdrop of prior research, we test these hypotheses to determine the impact of globalization as measured by FDI on FPLF using more recent data for an expanded panel of countries.

\section{Methodology}

3.1 Empirical Model

To examine the effect of FDI on FPLF, we specify the following empirical model:

$$
F P L F_{i, t}=\beta_{0}+\beta_{1} F P L F_{i, t-1}+\beta_{2} F D I_{i, t}+\beta_{3} \boldsymbol{X}_{i, t}+\mu_{i}+\varepsilon_{i, t}
$$

The outcome variable, FPLF, per definition of the World Bank, represents the female participation in the labor force as the percentage of the total labor force, which comprises people ages 15 and above who are economically active for country $i$ in year $t$. We also include one lag as an independent variable, producing a dynamic panel model. The one lag dependent variable is included in the model because past female labor force participation is expected to influence the current level of participation, considering only one lag of the FPLF as a useful abstraction.

The key independent variable of interest in our model is FDI, which represents the foreign direct investment net inflows as a percent of the GDP. This is our measure of globalization. Our key testable hypothesis boils down to conducting inference for the coefficient in front of FDI, namely $\beta_{2}$. If the estimate of $\beta_{2}$ turns out to be positive and statistically significant, we will be able to support the hypothesis that after controlling for the effect of the factors discussed in the paragraph below, globalization encourages women's employment.

Our model includes several control variables: $\boldsymbol{X}_{i, t}$ represents the matrix of the control variables under consideration that may affect women's labor force participation. 
These include GDP per capita as a measure of the overall development level of a country; fixed broadband subscription rate as a measure of infrastructure development; female tertiary school enrollments \% of gross enrollment as a measure of advanced education and skills level; female population as \% of the total population to capture women's role in the economy; and fertility rate as total births per female to gauge the likelihood of women participating in employment. The choice of control variables is guided by relevant literature. For example, Sajid (2014) shows how infrastructure development impacts employment. Okpak and Koyuncu (2017) show that education and fertility rates influence female labor force participation. Taşseven et al. (2016) find that GDP per capita is one of the key determinants of female labor force participation. Ospina and Tzvetkova (2017) show the effect of the female population on the number of women that participate in economic and business activities, all of which ultimately influence the FPLF. So, our goal is to estimate the impact of FDI on FLFP after accounting for the effect of these usual suspects.

Finally, $\mu_{i}$ represents the time-invariant country-specific fixed effects, and $\varepsilon_{i, t}$ are the idiosyncratic error components.

\subsection{Data Description}

To investigate the impact of globalization on FPLF, we utilize data with the variables described above available from the World Bank's World Development Indicators (WDI) database. Thus, our analysis is based on information from 99 countries across the world. This gives us the best possible global dataset rather than a subset of countries. We first extracted data for 175 countries from the World Bank's WDI. However, once missing observations across time are removed, we obtain a panel dataset for the 99 countries listed in Appendix A for the 2001-2018 period. The sample countries represent the following income groups: high income (38 countries) and low and middle income (61 countries). The World Bank categorizes countries into four sub-income groups a) low-income, b) lower-middle-income, c) upper-middle-income, and d) high-income countries based on income levels. However, for us to have sufficient observations in each income group to estimate the system GMM method successfully, we re-categorize countries into two income subgroups: a) high-income b) low- and middle-income (where we include low-income, lower-middle-income, and upper-middle-income countries) for the perceived differences between high-income countries and the rest of the world. We begin with the descriptive analysis presented in Table 1.

Table 1. Descriptive Statistics

\section{Full Sample:}

\begin{tabular}{llllll} 
Variable & Mean & SD & Min & Maximum & Count \\
\hline Female labor & 41.13 & 9.61 & 11.66 & 56.03 & 1782 \\
FDI inflows as \% of GDP & 6.82 & 22.21 & -58.32 & 451.64 & 1776 \\
Female tertiary education & 44.36 & 31.47 & 0.17 & 142.88 & 1782 \\
Fixed broadband subscription & 10.56 & 12.43 & 0 & 46.32 & 1701 \\
GDP per Capita & 15971.48 & 21160.56 & 194.87 & 111968.35 & 1782 \\
Female population & 50.29 & 2.98 & 23.29 & 54.56 & 1782 \\
Fertility rate & 2.597 & 1.47 & 0.86 & 7.67 & 1782 \\
\hline
\end{tabular}

Low-and Middle-income countries:

\begin{tabular}{llllll} 
Variable & Mean & SD & Min & Maximum & Count \\
\hline Female labor & 40.1 & 9.99 & 13.46 & 56.03 & 1098
\end{tabular}




\begin{tabular}{llllll} 
FDI inflows as \% of GDP & 4.42 & 5.54 & -37.15 & 55.08 & 1092 \\
Female tertiary education & 28.93 & 25.04 & 0.17 & 112.8 & 1098 \\
Fixed broadband subscription & 3.85 & 5.96 & 0 & 33.87 & 1017 \\
GDP per Capita & 3267.15 & 2860.2 & 194.87 & 12120.08 & 1098 \\
Female population & 50.5 & 1.22 & 47.97 & 54.56 & 1098 \\
Fertility rate & 3.15 & 1.59 & 1.08 & 7.67 & 1098 \\
\hline
\end{tabular}

\section{High-income countries:}

\begin{tabular}{llllll} 
Variable & Mean & SD & Min & Maximum & Count \\
\hline Female labor & 42.78 & 8.73 & 11.66 & 50.63 & 684 \\
FDI inflows as \% of GDP & 10.66 & 34.76 & -58.32 & 451.64 & 684 \\
Female tertiary education & 69.13 & 24.05 & 10.01 & 142.88 & 684 \\
Fixed broadband subscription & 20.53 & 12.84 & 0.01 & 46.32 & 684 \\
GDP per Capita & 36365.28 & 21874.29 & 7441.35 & 111968.4 & 684 \\
Female population & 49.96 & 4.54 & 23.29 & 54.21 & 684 \\
Fertility rate & 1.69 & 0.49 & 0.86 & 3.83 & 684 \\
\hline
\end{tabular}

The summary statistics for female labor force participation show that in the 99 countries under consideration, on average, 41 percent of the labor force is female, with a minimum value of about 12 percent and a maximum value of 56 percent. The average FDI inflows (as \% of GDP) across the entire sample is $6.82 \%$, with values of $10.66 \%$ and $4.42 \%$ for high-income and low- and middle-income countries, respectively. FDI for the total sample ranges from -58 to 452 percent, with some countries presenting as outliers. Female tertiary education across the full sample is $44.36 \%$, much higher in high-income countries (69.13\%) than low- and middle-income countries (28.93\%) over 2001-2018. As expected, the average GDP per capita for high-income countries $(\$ 36,365.28)$ is also much higher than the average for low- and middle-income countries $(\$ 3,267.15)$.

\subsection{Estimation Strategy}

Given the dynamic panel model we present above, the data are analyzed using system GMM. The GMM is an extension of instrumental variable methodology. Arellano and Bover (1995) and Blundell and Bond (1998) found that the lagged levels of the regressors provide weak instruments, which may lead to biased parameters. They proposed a system GMM estimator in which GMM is applied to a system of two equations: a) an equation in difference form instrumented by lagged levels and $b$ ) an equation in levels instrumented by lagged differences. The difference of explanatory variables is uncorrelated with the individual effects, though time-invariant country-specific fixed effects and other explanatory variables are allowed to be correlated (Blundell \& Bond, 1998) ${ }^{1}$.

We employ the system GMM estimation method for the following reasons:

1. To address endogeneity bias - Ullah et al. (2018) suggest that nearly $90 \%$ of papers published in premier journals may not address endogeneity bias adequately. Endogeneity arises when a) at least one of the regressors correlates with the error term; b) both the dependent variable and regressor simultaneously affect each other (simultaneity); c) omitting a relevant variable from the regression model which is correlated to at least one of the included explanatory variables causes endogeneity (i.e., the included variable corre-

\footnotetext{
1 Readers further interested on the topic can refer to Fukase (2010), Nawaz et al. (2014), Meschi et al. (2016), Roodman
} (2009), etc. 
lated to the error term). Endogeneity bias causes inconsistent estimates, which give misleading conclusions, wrong inference, and incorrect theoretical interpretations. Our model may suffer from potential endogeneity due to the issues described above. To deal with the potential endogeneity problem, we use the system GMM which utilizes the lagged values of the endogenous regressor as an instrument.

2. To control for the time unvarying country-specific effects: the system GMM estimation method is appropriate because the sample consists of 99 countries with specific characteristics such as culture and geography that do not vary over time.

3. To alleviate problems stemming from a violation of traditional model assumptions. The main advantage of GMM estimation is that the model need not be homoscedastic and serially independent (Nawaz et al., 2014). Another advantage is that it finds the parameter estimates by maximizing an objective function that subsumes the moment restriction such that the correlation between lagged regressor and the error term is zero.

4. Finally, the system GMM method is appropriate for our data because of the short time dimension of the panel data, with 18 years of data $(\mathrm{T})$, and a large country dimension of 99 countries $(N)(N>T)$. See Lee \& Lio (2016) for further details.

We verify that system GMM is a suitable estimation technique for our model and the data using appropriate statistical tests. The specification test results of the AR(2) with a pvalue greater than 0.1 reveal that the models do not suffer from second-order serial correlation. Sargan's test statistics also have p-values greater than 0.1 and show that the instruments used are not over-identified (Arellano \& Bond, 1991).

Next, we present the empirical results obtained from estimating equation (1) using the system GMM method.

\section{Empirical Results and Discussion}

We estimate equation (1) to examine the impact of FDI on FPLF for a panel of 99 countries during 2001-2018 using the system GMM model. We present three different sets of regressions in Table 2 as a robustness test of our results across income groups: column 1 shows the results for the full sample, column 2 shows the results for the low- and middle-income countries, and column 3 shows the results for high-income countries.

\subsection{Result pertaining to the key variable of interest}

The dependent variable in our model is the percentage of females ages 15 and above that participate in the labor force (FPLF). Focusing on our main research question, we see that FDI has a positive and significant impact on FPLF: a percentage point increase in FDI is associated with a 0.001 percentage point increase in FPLF. While the magnitude is small, this is a statistically significant result.

We also present these results separately for low- and middle-income countries in Column 2 and for high-income countries in Column 3 to see if the effect of FDI inflows is consistent across countries. While the FDI coefficients are positive and significant for both income subgroups, the estimated coefficient value is $0.001(\mathrm{p}<0.01)$ for high-income versus 0.007 $(p<0.10)$ for low- and middle-income economies. These results illustrate that FDI inflows have a stronger impact on FPLF in low- and middle-income countries than high-income countries: a one percent increase in FDI leads to a $0.001 \%$ increase in FPLF in high-income countries versus a $0.007 \%$ increase in FPLF for low- and middle-income countries. Alternatively, we can state with 90 percent confidence that a one percent increase in FDI leads to between $0.00034 \%$ and $0.00166 \%$ increase in FPLF for high-income countries as compared to an increase between $0.00042 \%$ and $0.01358 \%$ for low- and middle-income countries. 
Table 2. Impact of FDI on female participation in the labor force(FPLF) using system GMM approach.

\begin{tabular}{|c|c|c|c|}
\hline Explanatory Variables & Full Sample & Low \& Middle Income & High Income \\
\hline \multicolumn{4}{|l|}{ Lagged dependent variable } \\
\hline \multirow[t]{2}{*}{ Lagged FPLF } & $0.955^{* * *}$ & $0.959^{* * *}$ & $0.952^{* * *}$ \\
\hline & $(0.015)$ & $(0.014)$ & $(0.016)$ \\
\hline \multicolumn{4}{|l|}{ Key variable of interest } \\
\hline \multirow[t]{2}{*}{ FDI inflows as $\%$ of GDP } & $0.001^{* * *}$ & $0.007^{*}$ & $0.001^{* * *}$ \\
\hline & $(0.0004)$ & $(0.004)$ & $(0.0004)$ \\
\hline \multicolumn{4}{|l|}{ Control Variables } \\
\hline \multirow[t]{2}{*}{ GDP per Capita } & $0.00001^{* *}$ & 0.00002 & $0.00001^{*}$ \\
\hline & $(0.00000)$ & $(0.00002)$ & $(0.00000)$ \\
\hline \multirow[t]{2}{*}{ Fixed broadband subscription } & 0.003 & 0.005 & 0.003 \\
\hline & $(0.003)$ & $(0.006)$ & $(0.004)$ \\
\hline \multirow[t]{2}{*}{ Female tertiary education } & $-0.003^{*}$ & $-0.005^{* *}$ & 0.001 \\
\hline & $(0.002)$ & $(0.003)$ & $(0.002)$ \\
\hline \multirow[t]{2}{*}{ Female population } & $0.137^{* *}$ & $0.160^{*}$ & $0.091^{* * *}$ \\
\hline & $(0.060)$ & $(0.094)$ & $(0.026)$ \\
\hline \multirow[t]{2}{*}{ Fertility rate } & -0.007 & 0.014 & -0.164 \\
\hline & $(0.037)$ & $(0.034)$ & $(0.129)$ \\
\hline \multirow[t]{2}{*}{ Sargan's test } & 7.11 & 4.87 & 5.05 \\
\hline & $(p=0.53)$ & $(p=0.77)$ & $(p=0.75)$ \\
\hline \multirow[t]{2}{*}{$\operatorname{AR}(1)$} & -5.11 & -3.87 & -3.39 \\
\hline & $(p=0.00)$ & $(p=0.00)$ & $(p=0.00)$ \\
\hline \multirow[t]{2}{*}{$\mathrm{AR}(2)$} & -0.54 & -0.25 & -0.61 \\
\hline & $(p=0.59)$ & $(p=0.80)$ & $(p=0.54)$ \\
\hline Observations (N) & 1782 & 1098 & 684 \\
\hline No of Countries & 99 & 61 & 38 \\
\hline
\end{tabular}

Note : standard errors in parentheses, ${ }^{*} \mathrm{p}<0.1 ;{ }^{* *} \mathrm{p}<0.05 ;{ }^{* * *} \mathrm{p}<0.01$ indicate that the coefficient is significant at $10 \%, 5 \%$ and $1 \%$, respectively. The specification test results of the AR(2) with p-value greater than 0.1 reveal that the models do not suffer from second-order serial correlation. Also, Sargan's test statistics with p-value greater than 0.1 show that the instruments used are not over-identified (Arellano and Bond, 1991). Estimations are done using the pgmm function, a part of the $\mathrm{plm}$ package in $\mathrm{R}$.

These results are consistent with our provided conceptual framework for a relationship between FDI and women's FPLF. Since rising FDI suggests expanding economic globalization, it means more direct opportunities in productive assets both for high and non-high-income countries. As the latter income group has a lower technological level and infrastructural development, the FDI impact may be stronger in non-high-income countries. Our result is in unison with economic theories suggesting that returns on investment in low-and-middle income countries are higher than in high-income countries.

FDI also has a positive incentive for domestic investment that increases the demand for efficient labor. In addition, the increase in demand for efficient labor motivates the allocation of more resources for human capital development, such as better health and education, which contributes to increasing women's participation in the job market. The results are consistent with existing literature that find a positive association between FDI and women's employment (e.g., Chopra, 2019; Gaddis \& Pieters, 2012; Seguino and 
Grown, 2006) and other economic activities (e.g., Chakraborty \& Nunnenkamp, 2008; Ghimire \& Sharma Paudel, 2019; Raza et al., 2021, etc.)

\subsection{Results pertaining to the control variables:}

In addition to the primary variable of interest (FDI), we examine how other control variables influence female labor force participation. The results are mostly as expected. Below, we summarize the impact of each control variable as seen from both the full and sub-samples.

GDP per capita: GDP per capita is a proxy variable measuring the overall level of economic development (Gaddis \& Klasen, 2017). Therefore, women in countries with higher GDP per capita levels are more likely to join the labor force as there is a higher economic incentive. We see a positive and significant relationship between GDP per capita and FPLF in models other than the low-and-middle-income economies, where informal sector jobs and homemaking may have higher returns than formal sector employment.

Fixed broadband Subscription: We use the fixed broadband subscription as a proxy for the level of infrastructure development that would influence other economic activities and hence, the employment levels. No country can achieve the expected economic growth and development without adequate infrastructure (Sajid, 2014). Better infrastructure means the country is more developed in communication, transportation, and information and technology systems. Access to these resources improves women's mobility in society, increasing their participation in the labor force. Therefore, a positive effect is expected. While our estimates are positive, the results are statistically insignificant. It mandates a detailed analysis to ascertain the conditions under which it would have a significant impact, which is beyond the scope of this paper.

Female tertiary education: As the education level of women increases, it is expected to raise women's employment. The more educated and skilled individuals are, the greater their income potential because education increases opportunities for paid employment (Bills, 2018). Other papers such as Okpak and Koyuncu (2017) also show that education positively impacts FPLF. However, our results show that female education consistently correlates with FPLF negatively for the whole sample and low-and-middle-income countries. For the high-income group, it is positive but insignificant. So, it appears the results in the entire sample are influenced more by low- and middle-income countries. A potential explanation is a nonlinear (U-shaped) relationship between educational attainment and FPLF, as evident in many developing countries (Verick, 2014). The least educated women are most likely to participate in the informal sectors. Once women's education levels catch up and employment opportunities emerge, higher wages encourage them to join the labor force. Therefore, after a threshold level, women's participation increases with education. It is likely that most women with tertiary education are younger and are still in school as females' tertiary education is a relatively new phenomenon in many countries, and only younger ones have the opportunity. Since they are in school, they can't be working. At the same time, we get a positive relationship between FPLF and female tertiary education in high-income countries, though insignificant. Women in high-income countries do part-time jobs besides their education, so we see a positive relationship here. According to the 2009-2018 figures available from Statista, annually, about 17.5 million women were employed on a part-time basis in the US.

Female Population: As the female population rises, the number of women who are more likely to participate in economic and business activities increases, ultimately increasing the FPLF. Therefore, we expect a positive association between FPLF and the female population. We see a positive and significant relationship between FPLF and the female population, confirming our expectations for the whole sample, high-income and low- and middle-income groups. This finding aligns with existing literature such as Ospina and Tzvetkova (2017).

Fertility rate: One of the long-lasting and most prominent events in a woman's life is giving birth. As the fertility rate increases, the number of children per household swells 
up women's household responsibilities (daily housework, child caring, raising), thus discouraging engagement in other activities, including formal employment. Therefore, a negative effect is expected according to existing literature such as Okpak and Koyuncu (2017). Though we get expected results for the fertility rate, they are not significant in our model.

\subsection{Limitations of the study and the role of influential observations:}

While the study finds exciting answers to our research question, there are several caveats to this study: FDI is not the only proxy to measure globalization; there are several missing countries (most notably Australia, Brazil, Japan, New Zealand) due to missing observations for certain variables; different countries have different economic structures, and thus this study gives a general idea; due to inconsistent data availability, the model does not consider the cultural, social, and institutional variables to explain the labor force participation; data quality issues are a serious concern for developing countries. Even for those countries with data availability, there are severe issues with outliers when we mix countries with different socio-economic characteristics. For example, FDI inflows to Malta and Cyprus are around 500\% and 300\% of their GDP, respectively, whereas the rest of the world's FDI inflows are approximately at 100\% maximum, see Figure 1 and Figure 2, drawn to the same scale and visualizing the association between FPLF and FDI in our panel data by income group, with Figure 1 including all countries, while in Figure 2 the high-income Malta and Cyprus have been excluded.

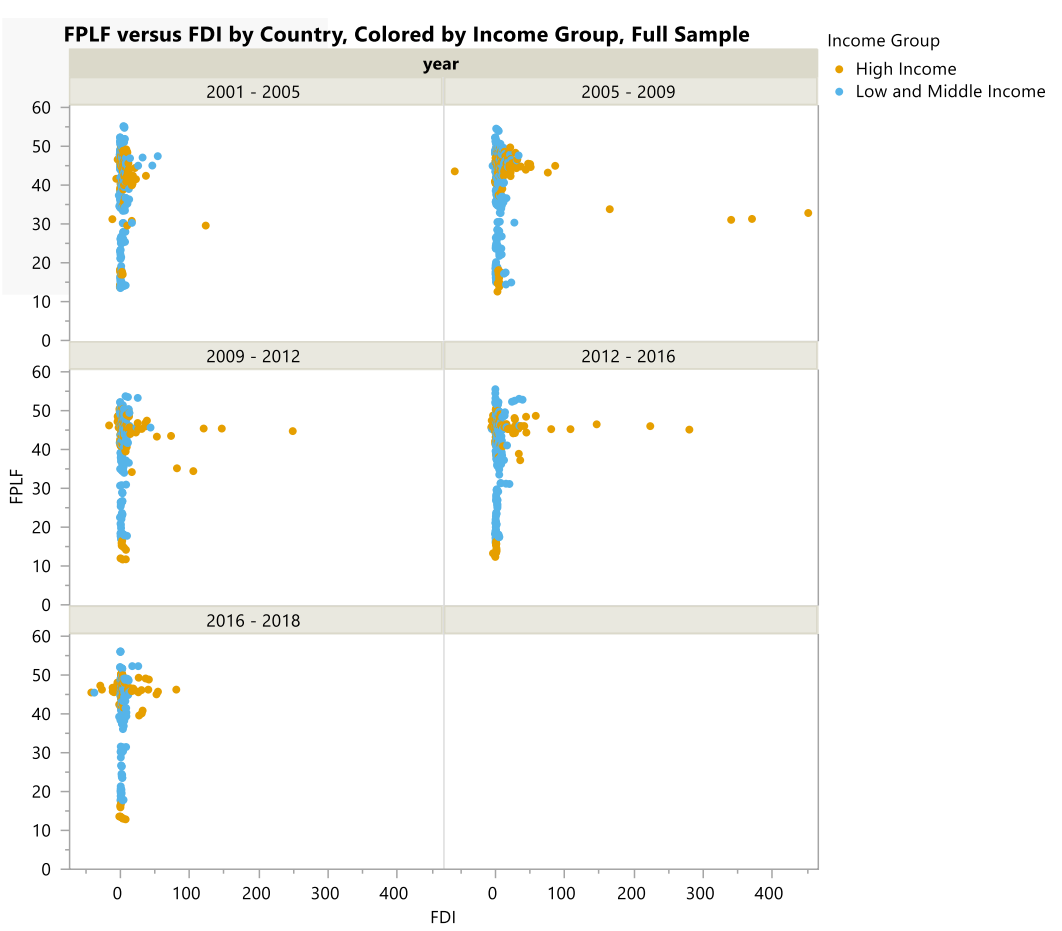

Figure 1. Scatterplots of FPLF versus FDI, with observations grouped in panels of 5 years and colored by income group, all countries included. The extreme outliers in the direction of FDI are observations from Malta and Cyprus. The fact that these observations are extreme outliers in the direction of the main explanatory factor, FDI, makes them prime suspects for having strong influence on the model estimation results as far as the effect of FDI. Source: Authors' calculation.

In our main analysis, we follow the existing literature and continue to include these countries in our study (Chopra, 2019; Erdogan \& Unver, 2015). However, when we repeat the analysis by removing these extreme outliers in the direction of our main explanatory factor, we find that FDI inflows are not significant anymore, thus confirming their influence on the estimation results. Now the main variables that positively affect female labor force participation are the female population and GDP per capita. These results show that 
a positive impact of FDI on employment and other economic outcomes should be considered critically. Countries such as Malta and Cyprus have often been suspected of money laundering scandals. The Cypriot banking system doubled in size over 2005-2010 due to the invasion of Russian and Ukrainian funds into the island's banks (Demetriades \& Vassileva, 2020). Future research should address these issues.

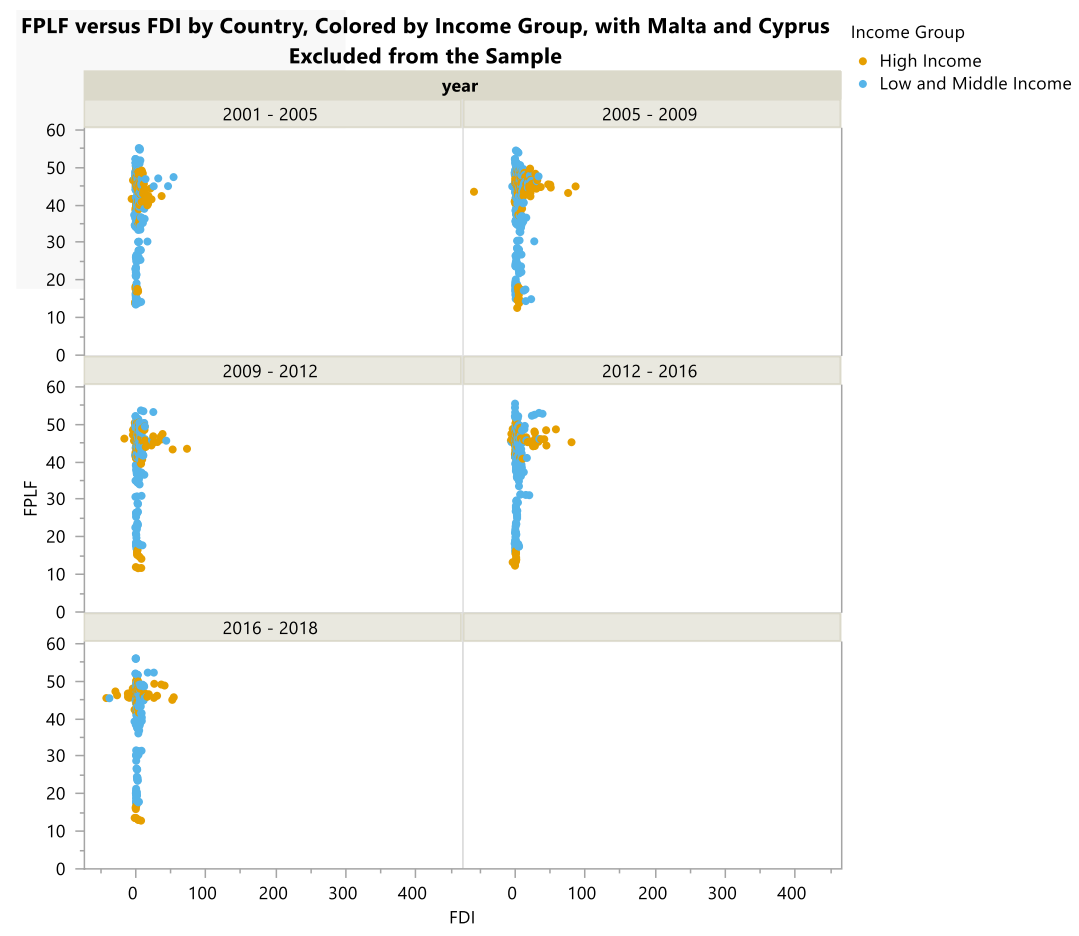

Figure 2. Scatterplots of FPLF versus FDI, scaled the same as the scatterplots in Figure 1, with observations grouped in panels of 5 years and colored by income group, with Malta and Cyprus excluded from the sample. Indeed, all other countries' FDI inflows range to about $100 \%$ of their GDP maximum. Source: Authors' calculation.

\section{Summary and Conclusions:}

In summary, this paper shows that FDI encourages women's economic participation to some extent, more substantially in low- and middle-income countries than in high-income countries. Additionally, countries with a higher GDP per capita, infrastructure development, and female population tend to have higher female labor force participation at the country level. These findings have important policy implications as women's employment prospects are essential to empowering women, a vital issue worldwide, but more critical in developing countries. If governments plan to benefit from globalization and empower women economically, they should invest more heavily in sectors that generate employment opportunities, such as enterprises that bring in FDI. This paper considers only economic perspectives in explaining the dynamics of female labor force participation; other political, cultural, social, and institutional analyses are beyond the scope of this paper, and future work should focus on incorporating such aspects.

\section{Supplementary Materials: none.}

Author Contributions: Conceptualization, Asrifa Hossain, Shankar Ghimire, Anna Valeva and Jessica Harriger-Lin; Data curation, Asrifa Hossain; Formal analysis, Asrifa Hossain, Shankar Ghimire, Anna Valeva and Jessica Harriger-Lin; Methodology, Asrifa Hossain, Shankar Ghimire and Anna Valeva; Software, Asrifa Hossain and Shankar Ghimire; Visualization, Asrifa Hossain and Anna Valeva; Writing - original draft, Asrifa Hossain, Shankar Ghimire, Anna Valeva and Jessica Harriger-Lin; Writing - review \& editing, Shankar Ghimire, Anna Valeva and Jessica Harriger-Lin.

Funding: This paper received no external funding. 
Data Availability Statement: Data are obtained from the World Development Indicators (WDI) database maintained by the World Bank.

Acknowledgments: The authors would like to thank conference participants at the Midwest Economics Conference 2021 and the School of Accounting, Finance, Economics, and Decision Sciences seminar participants for helpful comments and suggestions.

Conflicts of Interest: The authors declare no conflict of interest.

\section{References}

1. Abdulloev, I., Gang, I. N., \& Yun, M. S. (2014). Migration, education and the gender gap in labour force participation. The European Journal of Development Research, 26(4), 509-526. https://econpapers.repec.org/paper/ostwpaper/342.htm

2. Arellano, M., \& Bond, S. (1991). Some tests of specification for panel data: Monte Carlo evidence and an application to employment equations. The review of economic studies, 58(2), 277-297.

3. Arellano, M., \& Bover, O. (1995). Another look at the instrumental variable estimation of error-components models. Journal of econometrics, 68(1), 29-51.

4. Bills, C. A. (2018). Female Labor Force Participation and Tertiary Education: A Case Study of India and Brazil.

5. Blundell, R., \& Bond, S. (1998). Initial conditions and moment restrictions in dynamic panel data models. Journal of econometrics, $87(1), 115-143$.

6. Bussmann, M. (2009). The Effect of Trade Openness on Women's Welfare and Work Life. World Development, 37(6), 1027-1038. https://doi.org/10.1016/j.worlddev.2008.10.007

7. Carr, S. (2016). Investing in Equality: A Case for Motivating Gender Empowerment Through Foreign Direct Investment (Doctoral dissertation, Georgetown University).

8. Chakraborty, C., \& Nunnenkamp, P. (2008). Economic reforms, FDI, and economic growth in India: a sector level analysis. World development, 36(7), 1192-1212.

9. Chopra, C. (2019). Does Foreign Direct Investment Boost up Women Empowerment: A Panel Data Analysis of Developed and Developing Countries. Wealth: International Journal of Money, Banking \& Finance, 8(1).

10. Cooray, A., Dutta, N., \& Mallick, S. (2017). Trade Openness and Labor Force Participation in Africa: The Role of Political Institutions. Industrial Relations: A Journal of Economy and Society, 56(2), 319-350. https://doi.org/10.1111/irel.12175

11. Demetriades, P., \& Vassileva, R. (2020). Money Laundering and Central Bank Governance in The European Union. Journal of International Economic Law, 23(2), 509-533.

12. Erdogan, M., \& Unver, M. (2015). Determinants of foreign direct investments: Dynamic panel data evidence. International Journal of Economics and Finance, 7(5), 82.

13. Fukase, E. (2010). Revisiting linkages between openness, education and economic growth: System GMM approach. Journal of Economic Integration, 193-222.

14. Gaddis, I., \& Pieters, J. (2012). Trade liberalization and female labor force participation: Evidence from Brazil.

15. Gaddis, I., \& Klasen, S. (2014). Economic development, structural change, and women's labor force participation. Journal of Population Economics, 27(3), 639-681.

16. Ghimire, S., \& Paudel, N. S. (2019). R\&D, FDI, and Innovation: Examination of the Patent Applications in the OECD Countries. Journal of Development Innovations, 3(2), 1-11.

17. Lagarde, C., Summit, I. M. D. A. C., \& Peru. (n.d.). The Business Case for Women's Empowerment. IMF. Retrieved December 17, 2020, from https://www.imf.org/en/News/Articles/2016/11/18/SP111816-The-Business-Case-for-Womens-Empowerment

18. Lee, M. H., \& Lio, M. C. (2016). The impact of foreign direct investment on public governance and corruption in China. The China Review, 105-135.

19. Maqsood, F. (2014). Impact of Globalization on Female Labor Force Participation in the SAARC Region. Pakistan Journal of Social Sciences (PJSS), 34(2).

20. Meschi, E., Taymaz, E., \& Vivarelli, M. (2016). Globalization, technological change and labor demand: a firm-level analysis for Turkey. Review of World Economics, 152(4), 655-680.

21. Nawaz, S., Iqbal, N., \& Khan, M. A. (2014). The impact of institutional quality on economic growth: Panel evidence. The Pakistan Development Review, 15-31.

22. Okpak, Y., \& Koyuncu, J. Y. (2017). Does globalization affect female labor force participation: Panel evidence. Journal of Economics Bibliography, 4(4), 381-387.

23. Ortiz-Ospina, E., \& Tzvetkova, S. (2017). Working women: Key facts and trends in female labor force participation. Our world in data (blog). October 16, 2017.

24. Ouedraogo, R., \& Marlet, E. (2018). Foreign Direct Investment and Women Empowerment: New Evidence on Developing Countries. IMF Working Papers, 18(25), 1. https://doi.org/10.5089/9781484339732.001

25. Raza, S. A., Shah, N., \& Arif, I. (2021). Relationship between FDI and economic growth in the presence of good governance system: Evidence from OECD Countries. Global Business Review, 22(6), 1471-1489.

26. Richards, D. L., \& Gelleny, R. (2007). Women's status and economic globalization. International Studies Quarterly, 51(4), 855876. 
27. Roodman, D. (2009). How to do xtabond2: An introduction to difference and system GMM in Stata. The stata journal, 9(1), 86136.

28. Sajid, S. (2014). Political Economy of Gender Equality: Case Study of Pakistan. 2, 33.

29. Seguino, S., \& Grown, C. (2006). Gender equity and globalization: Macroeconomic policy for developing countries. Journal of International Development: The Journal of the Development Studies Association, 18(8), 1081-1104.

30. Statista (2021). Number of part-time employed women in the United States from 1990 to 2020. Available at https://www.statista.com/statistics/192337/number-of-part-time-employed-women-in-the-us-since-1990/

31. Taşseven, Ö., Altaş, D., \& Turgut, Ü. N. (2016). The determinants of female labor force participation for OECD countries. Uluslararası Ekonomik Araştırmalar Dergisi, 2(2), 27-38.

32. Ullah, S., Akhtar, P., \& Zaefarian, G. (2018). Dealing with endogeneity bias: The generalized method of moments (GMM) for panel data. Industrial Marketing Management, 71, 69-78.

33. Verick, S. (2014). Female labor force participation in developing countries. IZA World of Labor.

34. Vijaya, R. M., \& Kaltani, L. (2007). Foreign direct investment and wages: a bargaining power approach. Journal of World-Systems Research, 83-95. https://doi.org/10.5195/jwsr.2007.361

35. Wacker, K. M., Cooray, A., \& Gaddis, I. (2017). Globalization and Female Labor Force Participation in Developing Countries: An Empirical (Re-)Assessment. In B. J. Christensen \& C. Kowalczyk (Eds.), Globalization (pp. 545-583). Springer Berlin Heidelberg. https://doi.org/10.1007/978-3-662-49502-5_22

\section{Appendix A}

\section{List of countries}

\begin{tabular}{|c|c|c|c|c|c|}
\hline Albania & Algeria & Argentina & Armenia & Azerbaijan & Bangladesh \\
\hline Belarus & Belgium & Belize & Benin & Brunei Darussalam & Bulgaria \\
\hline Burkina Faso & Burundi & Cabo Verde & Cambodia & Cameroon & Canada \\
\hline Chad & Chile & China & Colombia & Croatia & Cyprus \\
\hline Czech Republic & Denmark & Egypt, Arab Rep. & El Salvador & Estonia & Ethiopia \\
\hline Finland & France & Georgia & Ghana & Greece & Honduras \\
\hline $\begin{array}{l}\text { Hong Kong SAR, } \\
\text { China }\end{array}$ & Hungary & Iceland & India & Indonesia & Iran, Islamic Rep. \\
\hline Ireland & Israel & Italy & Jordan & Korea, Rep. & Kyrgyz Republic \\
\hline Lao PDR & Latvia & Lithuania & Luxembourg & Macao SAR, China & Madagascar \\
\hline Malaysia & Malta & Mauritania & Mauritius & Mexico & Moldova \\
\hline Mongolia & Morocco & Mozambique & Nepal & Netherlands & Niger \\
\hline North Macedonia & Norway & Oman & Pakistan & Panama & Philippines \\
\hline Poland & Portugal & Qatar & Romania & Russian Federation & Rwanda \\
\hline Saudi Arabia & Senegal & Serbia & Slovak Republic & Slovenia & Spain \\
\hline St. Lucia & Sudan & Sweden & Switzerland & Tajikistan & Tanzania \\
\hline Thailand & Tunisia & Uganda & Ukraine & United Kingdom & United States \\
\hline Uzbekistan & Vietnam & West Bank and Gaza & & & \\
\hline
\end{tabular}

